\title{
DOSTĘPNOŚĆ PRZESTRZENNA A RUCH TURYSTYCZNY \\ - STUDIUM PRZYPADKU STREFY NADMORSKIEJ WYBRZEŻA BAŁTYKU
}

\section{Wstęp}

Strefy wybrzeży nadmorskich to najczęściej odwiedzane w skali świata obszary recepcji turystycznej. Wynika to z dominującej roli, jaką odgrywa nieprzerwanie turystyka wypoczynkowa na tle innych form ruchu turystycznego. Jest to również związane $\mathrm{z}$ najwyższym pod względem ilościowym poziomem zagospodarowania turystycznego wybrzeży, zwłaszcza $\mathrm{w}$ zakresie bazy noclegowej. Według oficjalnych danych statystycznych GUS w roku 2015 w Polsce w obu województwach nadmorskich znajdowało się ponad 200 tys. miejsc noclegowych z ogółu ponad 600 tys. miejsc noclegowych. Należy mieć na uwadze, że udział pojemności noclegowej wybrzeża w skali kraju może być znacznie większy, co wynika ze znacznego odsetka $\mathrm{w}$ bazie noclegowej obszaru wielu obiektów sezonowych, nieujmowanych w oficjalnych zestawieniach GUS. Potwierdzeniem tego mogą być badania M. MIEDZIŃSKIEGO (2011), zwłaszcza dotyczące regionu Kołobrzegu, oraz K. PARZYCHA (2015) w Łebie. Oprócz bazy noclegowej istotnym czynnikiem potencjalnie wpływającym na skalę ruchu turystycznego jest dostępność turystyczna obszaru. Dotyczy to dostępności w szeroko rozumianym znaczeniu - dostępności czasowej, przestrzennej, transportowej oraz ekonomicznej. 
Zagadnienie dostępności turystycznej było już podejmowane w literaturze. Dotychczasowe badania koncentrowały się wokół dostępności strefy wybrzeża w województwie zachodniopomorskim (KOMORNICKI i in. 2010, MILEWSKI 2010).

\section{Cel opracowania i metoda badawcza}

W niniejszym opracowaniu dokonano analizy związku dostępności obszaru $\mathrm{z}$ ruchem turystycznym. Do opracowania przyjętego zagadnienia wybrano 40 ośrodków położonych bezpośrednio w strefie brzegowej wybrzeża oraz 40 miejscowości $\mathrm{w}$ różnych częściach kraju. W celu określenia dostępności miejscowości nadmorskich z pozostałych części kraju wybrano wszystkie miasta wojewódzkie, większość miast z liczbą powyżej 100 tys. mieszkańców oraz wybrane charakterystyczne miejscowości - węzły komunikacyjne rozmieszczone na obszarze całej Polski.

Dokonano oszacowania odległości czasowo-przestrzennej między każdym z 40 ośrodków położonych na wybrzeżu a pozostałymi 40 wybranymi miejscowościami w różnych częściach kraju. Dla każdej z miejscowości wybrzeża określono trzy rodzaje odległości - odległość rzeczywistą (odległość w linii prostej), najbliższą odległość drogową, odległość czasową (najkrótszy czas przejazdu) pomiędzy każdą miejscowością kraju a wybranymi 40 na obszarze Polski. Następnie dla każdego ośrodka nadmorskiego określono średnie odległości rzeczywiste, średnie najkrótsze odległości drogowe oraz średni najkrótszy czas przejazdu pomiędzy nimi a wybranymi miastami na obszarze Polski. W drugiej części opracowania zestawiono uzyskane wyniki $\mathrm{z}$ danymi odnoszącymi się do ruchu turystycznego na podstawie danych Banku Danych Lokalnych GUS w celu określenia związku dostępności przestrzennej miejscowości nadmorskich z danymi ilościowymi dotyczącymi rejestrowanego ruchu turystycznego na wybrzeżu. W analizie związku dostępności poszczególnych miejscowości nadmorskich z rejestrowanym ruchem turystycznym posłużono się analizą współczynników korelacji rang Spearmana oraz metodą grupowania Warda. Do oceny zależności dostępności ośrodków nadmorskich $\mathrm{z}$ rejestrowanym ruchem turystycznym wybrano grupę 32 miejscowości ze względu na brak bądź niekompletność danych na temat ruchu turystycznego dla ośmiu miejscowości. Ruch turystyczny w ośrodkach nadmorskich opisano przy użyciu danych dotyczących osób 
korzystających $\mathrm{z}$ bazy noclegowej w poszczególnych miejscowościach oraz liczby udzielonych noclegów i średniej długości pobytu turysty. Warto zaznaczyć, że dane uzyskane z GUS z pewnością nie są wyczerpujące, brak jednak w skali całego wybrzeża i kraju innych kompleksowych opracowań statystycznych dotyczących zagospodarowania noclegowego i wykorzystania bazy noclegowej obszaru.

\section{Analiza wyników}

Dostępność obszaru stanowi bardzo ważny element atrakcyjności turystycznej obszaru. Dotyczy do dostępności w szerokim jej rozumieniu, zarówno czasowym, przestrzennym, jak i ekonomicznym. Niewielka odległość przestrzenna, a zwłaszcza krótki czas podróży z miejsca zamieszkania do celu podróży to często czynniki decydujące o wyborze przez turystę konkretnej destynacji turystycznej.

Oszacowania odległości przestrzennych i czasowych dokonano na podstawie obliczeń uzyskanych przy wykorzystaniu witryny internetowej www. kalkulatorodległości.com. Jak już wspomniano, przeprowadzono szacunek odległości rzeczywistych, najkrótszych odległości drogowych oraz najkrótszych potencjalnie odległości czasowych pomiędzy 40 ośrodkami nadmorskimi a 40 miastami wybranymi z obszaru całej Polski.

Miejscowości nadmorskie Pobrzeża Gdańskiego i wschodniej części Pobrzeża Koszalińskiego są położone w znacznie mniejszej odległości geograficznej od południka środka geometrycznego Polski. Fakt ten implikuje znacznie bliższe odległości rzeczywiste (odległości w linii prostej) ośrodków położonych $\mathrm{w}$ tej części Pobrzeża Bałtyku z resztą terytorium Polski w porównaniu z miejscowościami Pobrzeża Szczecińskiego. Potwierdzeniem tego są dystanse pomiędzy poszczególnymi miejscowościami nadmorskimi wybrzeża i miastami z pozostałej części terytorium Polski (tab. 1). Znacznie większe odległości rzeczywiste od pozostałych miejscowości kraju dotyczą miejscowości Pobrzeża Szczecińskiego. Najdłuższe odległości rzeczywiste w grupie badanych ośrodków miejskich oddzielają najdalej na zachód wysuniętą miejscowość polskiego wybrzeża Świnoujście od wybranych miejscowości południowo-wschodniej części Polski (są to dystanse: Świnoujście-Przemyśl - 743,65 km, Świnoujście-Zamość - 707,27km). 


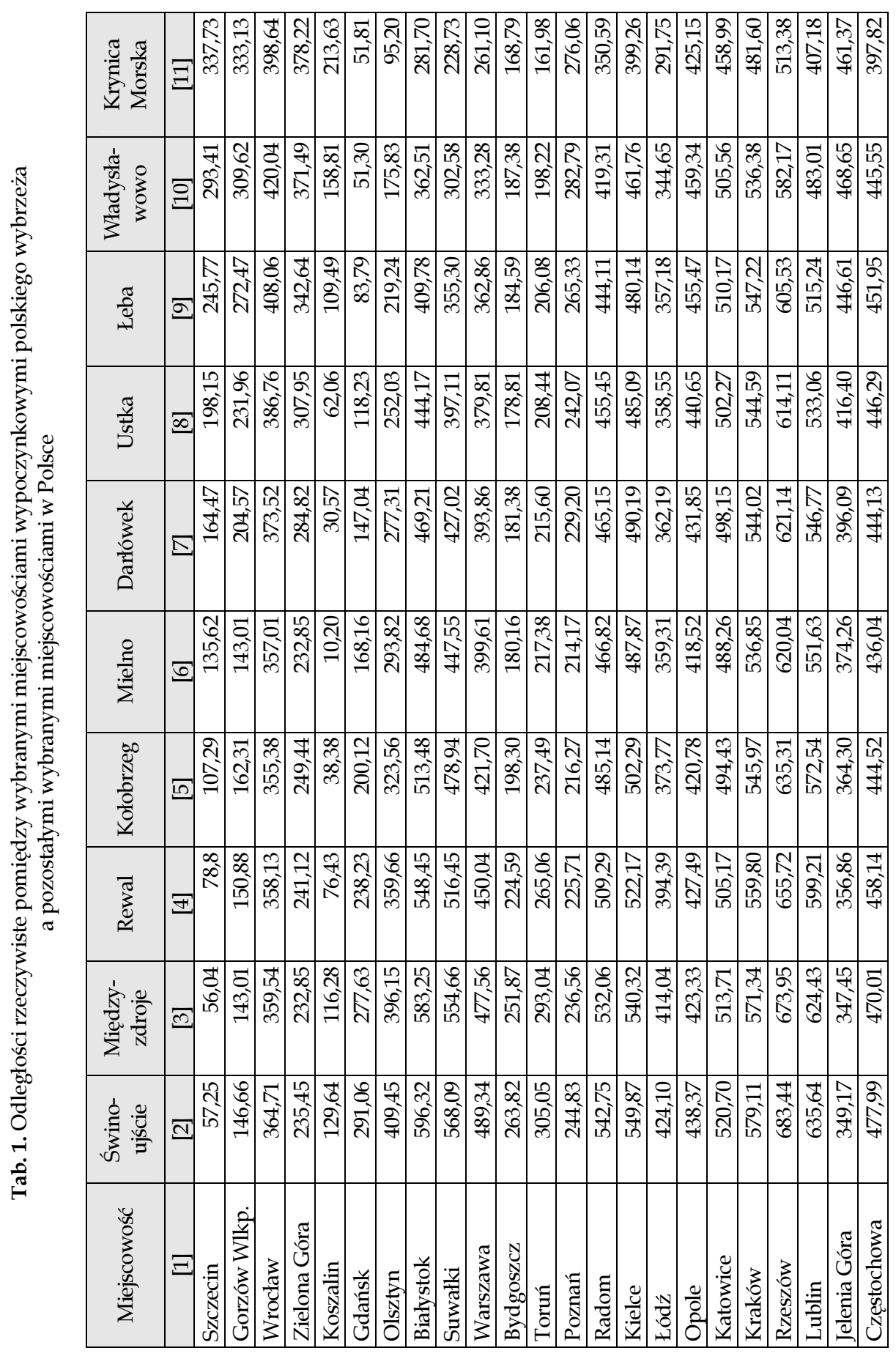




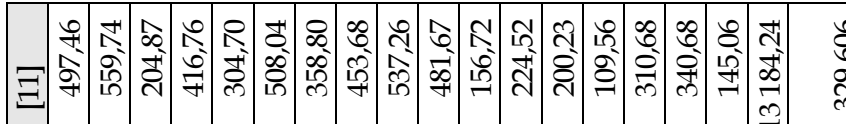

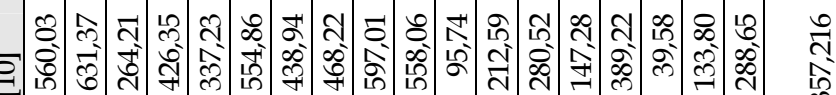

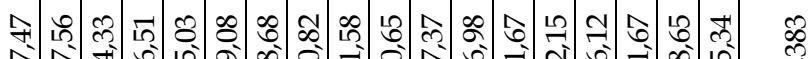

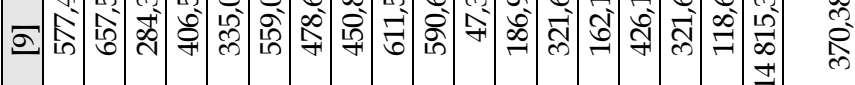

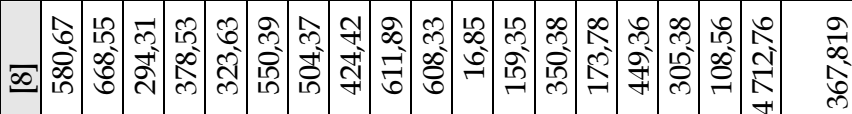

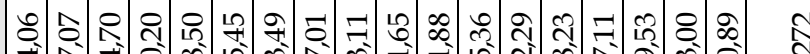

వ

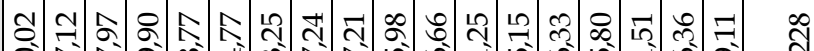

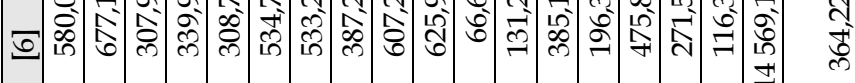

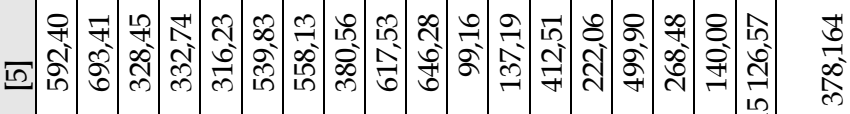

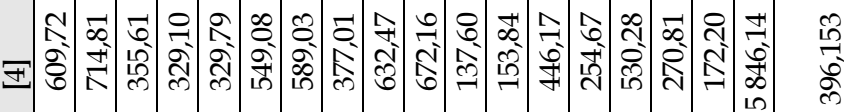

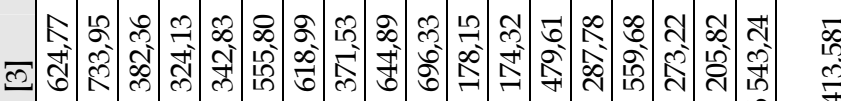

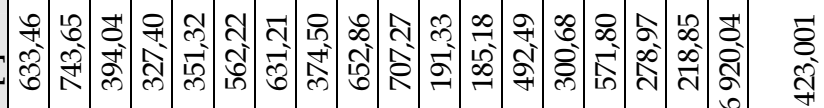

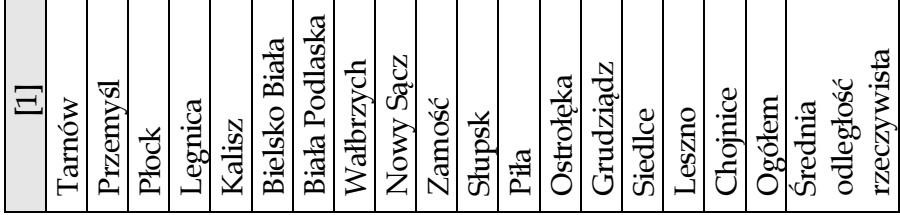

0
0
0
$\frac{0}{3}$
0
0
0
0
0
$\frac{0}{0}$
0
0
0
0
0
N 


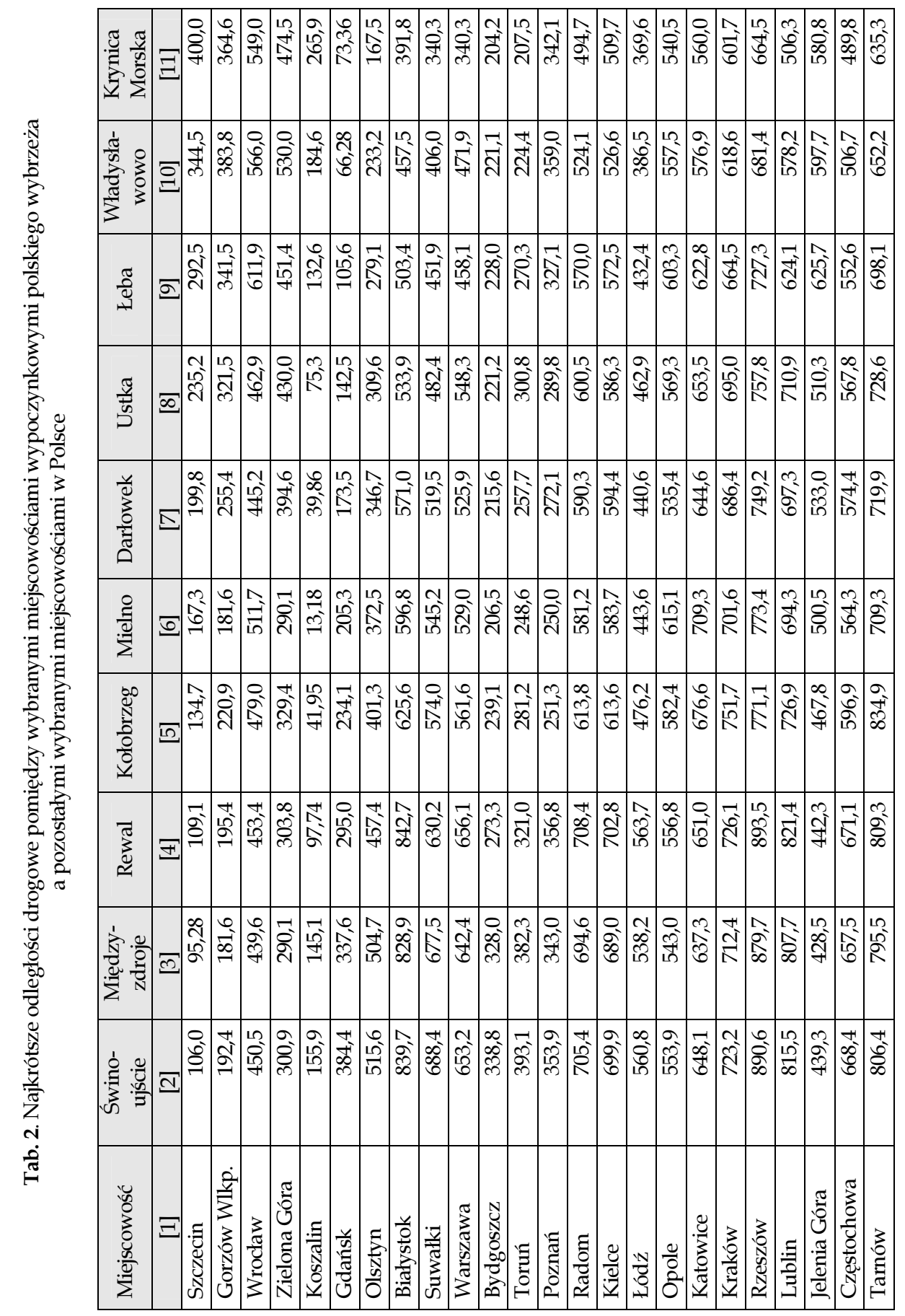




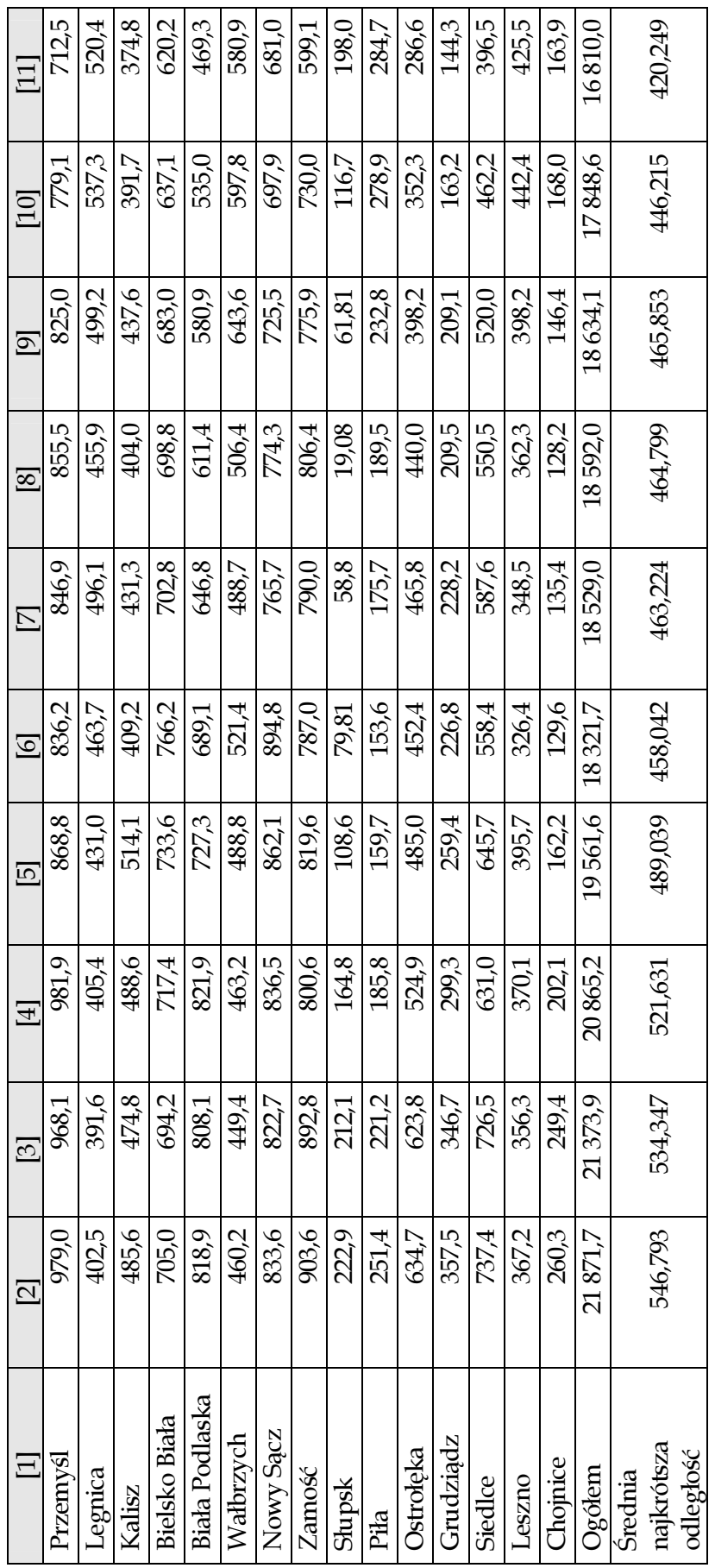


[1]

$\frac{\sqrt[2]{2}}{\sqrt[N]{2}}$

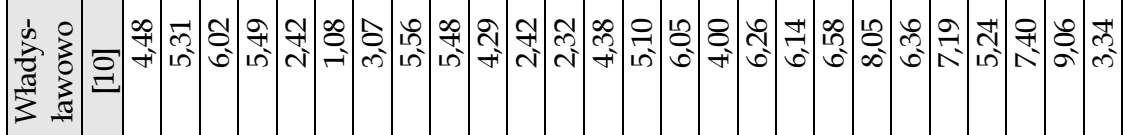

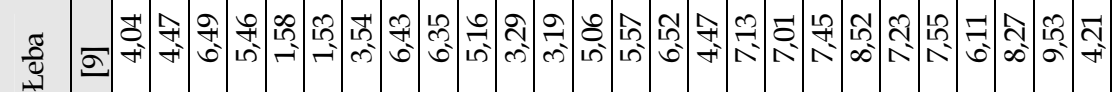

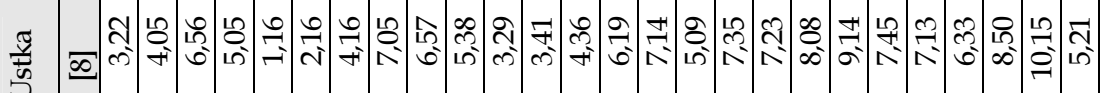

过

.ี

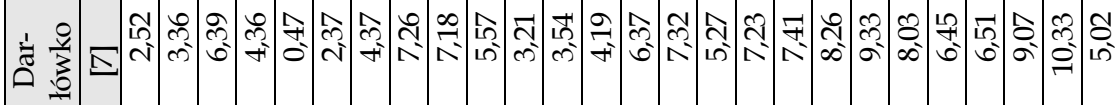

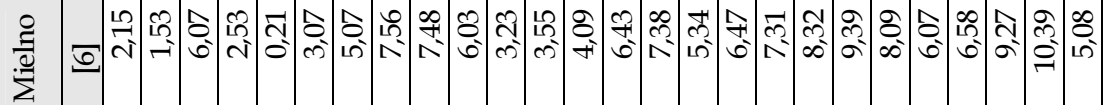

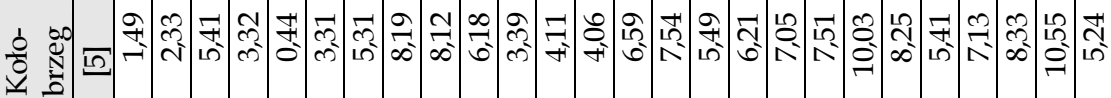

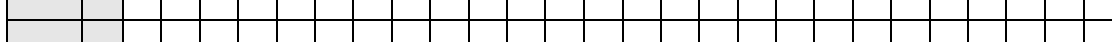

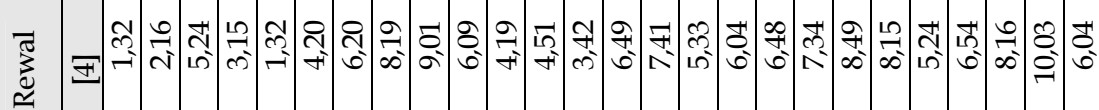

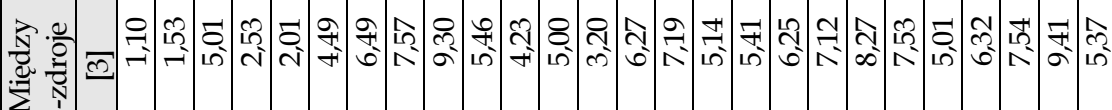

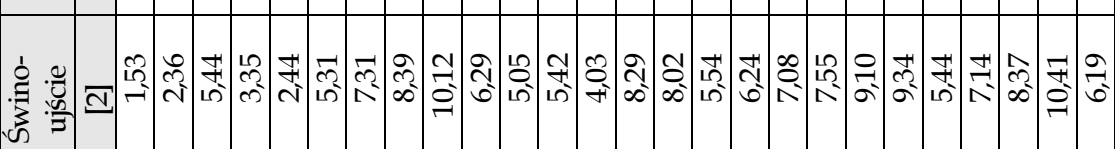

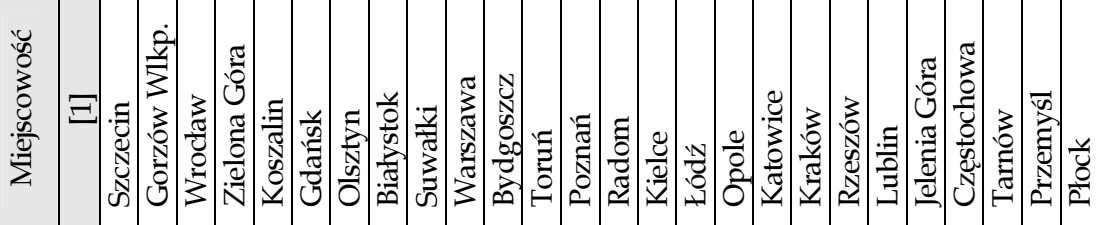




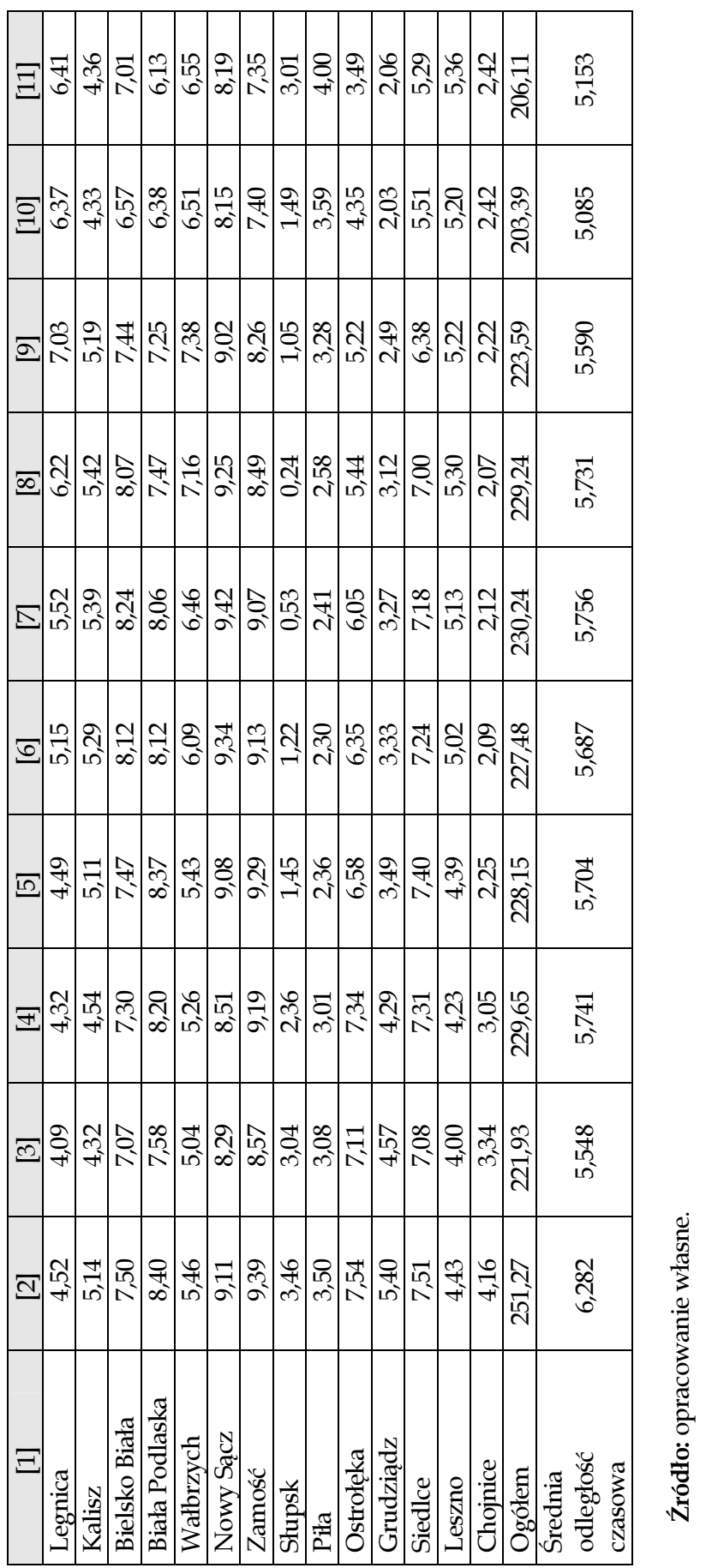


Najdalej na wschód wysuniętą miejscowość polskiego wybrzeża Krynicę Morską oddzielają znacznie krótsze odległości z najdalej położonymi wybranymi do analizy miejscowościami kraju (są to: Krynica Morska-Przemyśl - 559,74 km, Krynica Morska-Nowy Sącz - 537,26 km). Najdalej na północ wysuniętą miejscowość Jastrzębią Górę oddzielają najdłuższe dystanse z Nowym Sączem $(604,34$ km) oraz z Rzeszowem $(589,51$ km).

Analiza najkrótszych odległości drogowych pokazuje znacznie większy dystans pomiędzy miejscowościami nadmorskimi i pozostałą częścią kraju w relacji do analogicznych odległości rzeczywistych (odległości w linii prostej; tab. 2). Wynika to ze specyfiki układu sieci drogowej determinowanego w różnych częściach terytorium kraju czynnikami przyrodniczymi, historycznymi czy społeczno-ekonomicznymi. Najdłuższy dystans w grupie najkrótszych odległości drogowych oddzielających miejscowości wybrzeża od pozostałych wybranych miejscowości kraju dzieli Świnoujście i następujące miasta: Zamość (903,6 km), Rzeszów (890,6 km), Białystok (839,7 km) i Nowy Sącz $(833,6$ km). Jastrzębią Górę oddziela najdłuższy dystans z Przemyślem $(786,4 \mathrm{~km})$ oraz z Nowym Sączem $(705,12)$ km. Najdalej na wschód wysunięta na wybrzeżu Krynica Morska najdłuższy dystans w grupie najkrótszych odległości drogowych posiada z Przemyślem $(712,5 \mathrm{~km})$, Nowym Sączem $(681 \mathrm{~km})$ oraz z Rzeszowem $(664,5 \mathrm{~km})$.

Analiza najkrótszych odległości czasowych potrzebnych do pokonania odległości pomiędzy miejscowościami wybrzeża a wybranymi miejscowościami pozostałej części kraju nie jest odzwierciedleniem najkrótszych odległości drogowych, co wynika ze zróżnicowania jakości sieci drogowej w Polsce, a zwłaszcza ze zróżnicowanej dostępności dróg o najwyższych parametrach technicznych umożliwiających pokonywanie trasy z najwyższą średnią prędkością (autostrady i drogi ekspresowe, tab. 3).

Najdłuższy czasowy w grupie najkrótszych odległości czasowych pomiędzy miejscowościami wybrzeża i pozostałej części kraju dzieli Kołobrzeg od Przemyśla (10 h i 55 min), Świnoujście od Przemyśla (10 h i 41 min), Mielno od Przemyśla (10 h i 39 min) oraz Darłówko od Przemyśla (10 h i 15 min) oraz Świnoujście od Suwałk (10 h i 12 min), Świnoujście od Zamościa (9 h i 39 min) i Świnoujście od Lublina (9 h i 33 min)y. Najdalej wysunięte na północ i na wschód Jastrzębia Góra oraz Krynica Morska to najdalsze w grupie najkrótszych odległości czasowych miejscowości od Przemyśla (odpowiednio 9 h i 6 min oraz 9 h i 10 min) i Nowego Sącza (odpowiednio 8 h i 15 min oraz 8 h i $19 \mathrm{~min})$. 
Dokonano obliczenia średnich odległości rzeczywistych, średnich najkrótszych odległości drogowych oraz średnich odległości czasowych pomiędzy miejscowościami wybrzeża a 40 wybranymi miejscowościami pozostałej części Polski. Najbliższe średnie odległości rzeczywiste w analizie odległości pomiędzy 40 wybranymi miejscowościami wybrzeża a 40 wybranymi miejscowościami pozostałej części kraju posiadają miejscowości Stegna $(399,59$ km), Sztutowo $(407,85)$, Gdańsk $(408,09)$, Gdynia $(409,19)$ i Sopot $(412,75$, tab. 4). Najdalsze średnie odległości dotyczą Świnoujścia $(546,79 \mathrm{~km})$, Wisełki $(535,73 \mathrm{~km})$, Międzyzdrojów $(534,3)$, Pogorzelicy $(532,13)$ oraz Niechorza $(529,30)$.

Tab. 4. Średnie odległości przestrzenne i czasowe miejscowości wypoczynkowych wybrzeża i wybranych pozostałych miejscowości w Polsce

\begin{tabular}{|l|c|c|c|}
\hline \multicolumn{1}{|c|}{ Miejscowość } & $\begin{array}{c}\text { Średnia najbliższa } \\
\text { odległość drogowa }\end{array}$ & $\begin{array}{c}\text { Średnia odległość } \\
\text { rzeczywista }\end{array}$ & $\begin{array}{c}\text { Średnia najbliższa } \\
\text { odległość czasowa }\end{array}$ \\
\hline Wisełka & {$[2]$} & {$[3]$} & {$[4]$} \\
\hline Świnoujście & 535,734 & 410,216 & 6,13 \\
\hline Międzyzdroje & 546,793 & 423,001 & 6,28 \\
\hline Międzywodzie & 534,347 & 413,581 & 5,55 \\
\hline Dziwnów & 528,072 & 406,198 & 6,14 \\
\hline Łukęcin & 524,225 & 405,053 & 6,11 \\
\hline Pobierowo & 526,230 & 400,719 & 6,11 \\
\hline Pustkowo & 524,275 & 398,319 & 6,04 \\
\hline Trzęsacz & 522,990 & 397,403 & 6,07 \\
\hline Rewal & 525,415 & 396,829 & 6,06 \\
\hline Niechorze & 521,631 & 396,153 & 6,14 \\
\hline Pogorzelica & 529,300 & 394,118 & 6,13 \\
\hline Mrzeżyno & 532,134 & 392,871 & 6,18 \\
\hline Rogowo & 520,918 & 382,209 & 6,11 \\
\hline Grzybowo & 506,330 & 386,496 & 6,25 \\
\hline Dźwirzyno & 509,449 & 380,796 & 6,17 \\
\hline Kołobrzeg & 511,224 & 383,719 & 6,30 \\
\hline Sianożęty & 489,039 & 378,164 & 6,10 \\
\hline Ustronie Morskie & 487,542 & 375,925 & 6,17 \\
\hline Gąski & 480,222 & 373,363 & 6,14 \\
\hline Sarbinowo & 471,253 & 364,055 & 6,14 \\
\hline Mielno & 469,043 & 368,889 & 6,22 \\
\hline Łazy & 458,042 & 364,228 & 6,19 \\
\hline Dąbki & 490,534 & 373,153 & 6,33 \\
\hline Darłówko & 475,449 & 375,299 & 6,26 \\
\hline & 463,224 & 369,272 & 6,16 \\
\hline
\end{tabular}




\begin{tabular}{|l|c|c|c|}
\hline \multicolumn{1}{|c|}{$[1]$} & {$[2]$} & {$[3]$} & {$[4]$} \\
\hline Jarosławiec & 477,145 & 372,754 & 5,89 \\
\hline Ustka & 464,799 & 367,819 & 6,13 \\
\hline Łeba & 465,853 & 370,383 & 5,59 \\
\hline Białogóra & 453,804 & 368,928 & 5,26 \\
\hline Dębki & 462,321 & 373,709 & 5,27 \\
\hline Karwia & 452,857 & 369,925 & 5,17 \\
\hline Jastrzębia Góra & 449,787 & 369,252 & 5,19 \\
\hline Władysławowo & 446,214 & 357,216 & 5,08 \\
\hline Jastarnia & 471,912 & 354,506 & 6,00 \\
\hline Hel & 479,297 & 347,102 & 6,27 \\
\hline Gdynia & 409,191 & 327,947 & 4,36 \\
\hline Sopot & 412,756 & 332,710 & 4,32 \\
\hline Gdańsk & 408,093 & 324,640 & 4,45 \\
\hline Stegna & 399,597 & 9,990 & 5,09 \\
\hline Sztutowo & 407,858 & 323,548 & 5,16 \\
\hline Krynica Morska & 420,249 & 329,606 & 5,15 \\
\hline
\end{tabular}

Źródło: opracowanie własne.

Najdłuższe średnie dystanse $\mathrm{w}$ grupie najkrótszych odległości drogowych miejscowości wybrzeża i pozostałych 40 wybranych miast pozostałej części kraju mają Świnoujście $(423,01 \mathrm{~km})$, Międzyzdroje $(413,58 \mathrm{~km})$, Wisełka $(410,21)$ oraz Międzywodzie $(406,198)$. Najkrótsze średnie odległości charakteryzują Sztutowo $(323,54)$, Gdańsk $(324,64)$, Gdynię $(327,94)$, Krynicę Morską $(329,60)$ i Stegnę $(332,71 \mathrm{~km})$.

Miejscowości nadmorskie Pobrzeża Szczecińskiego oraz zachodniej części Pobrzeża Koszalińskiego mają znacznie wyższe średnie najkrótsze odległości drogowe z wybranymi miejscowościami pozostałej części kraju w porównaniu z ośrodkami wschodniej części Pobrzeża Koszalińskiego oraz miejscowościami Pobrzeża Gdańskiego.

Analiza średnich najkrótszych odległości czasowych dzielących miejscowości wybrzeża od pozostałej części kraju wskazuje, że najkrótszy średni dystans dzieli pozostałą część kraju z Sopotem (4 h i 32 minuty), Gdynią (4 h i 36 minut), Gdańskiem (4 h i $45 \mathrm{~min}$ ), Stegną (5 h i 9 min) oraz ze Sztutowem (5 h $16 \mathrm{~min}$ ). Najdłuższe średnie w grupie najkrótszych odległości czasowych dzielących miejscowości wybrzeża od wybranych ośrodków miejskich z pozostałej części kraju mają Łazy (6 h i $33 \mathrm{~min}$ ), Świnoujście (6 h i $28 \mathrm{~min}$ ), Hel (6 h i $27 \mathrm{~min}$ ), Dąbki (6 h i $26 \mathrm{~min}$ ), Rogowo (6 h i $25 \mathrm{~min}$ ) i Sarbinowo (6 h i $22 \mathrm{~min})$. 
Różnica czasu pomiędzy miejscowościami o najdłuższej i najkrótszej średniej odległości czasowych dzielących je od pozostałej części kraju wynosi 2 godziny i 1 minuta (Sopot - 4 h i 32 min i Łazy - 6 h i 33 min). Zauważalny jest znacznie krótszy dystans czasowy dzielący miejscowości Pobrzeża Gdańskiego i pozostałą częścią kraju w porównaniu z miejscowościami Pobrzeża Szczecińskiego. Obraz ten nieco modyfikują pojedyncze peryferyjne trudno dostępne ze względu na położenie i warunki środowiska geograficznego miejscowości ( Hel, Łazy, Dąbki).

Badania ruchu turystycznego $w$ Polsce $z$ uwagi na brak wyczerpujących danych odnośnie do zagospodarowania noclegowego, co za tym idzie - danych o ruchu turystycznym, nastręczają pewnych trudności. Głównym źródłem danych $\mathrm{w}$ szerszej skali statystyki dotyczącej poszczególnych gmin i miejscowości są dane statystyczne Banku Danych Lokalnych GUS.

W niniejszej pracy do opracowania współzależności dostępności przestrzennej i ruchu turystycznego posłużono się tymi danymi GUS dotyczącymi liczby korzystających z noclegów ogółem (turystów), liczby udzielonych noclegów ogółem oraz średniej długości pobytu (tab. 5). W analizie wykorzystano dane za rok 2014. Ze względu na braki danych wyselekcjonowano 32 miejscowości nadmorskie.

Tab. 5. Podstawowe dane o ruchu turystycznym w wybranych miejscowościach Pobrzeża Bałtyku

\begin{tabular}{|l|c|c|c|}
\hline \multicolumn{1}{|c|}{ Miejscowość } & Turyści ogółem & Udzielone noclegi & $\begin{array}{c}\text { Średnia długość } \\
\text { pobytu turysty }\end{array}$ \\
\hline \multicolumn{1}{|c|}{$[1]$} & {$[2]$} & {$[3]$} & {$[4]$} \\
\hline Wisełka & 5385 & 21708 & 4,03 \\
\hline Świnoujście & 232825 & 1454669 & 6,25 \\
\hline Międzyzdroje & 135499 & 606178 & 4,47 \\
\hline Międzywodzie & 728 & 2044 & 2,81 \\
\hline Dziwnów & 15986 & 112672 & 7,05 \\
\hline Pobierowo & 6307 & 36949 & 5,86 \\
\hline Rewal & 3444 & 33089 & 9,61 \\
\hline Niechorze & 128190 & 760358 & 5,93 \\
\hline Mrzeżyno & 4505 & 36876 & 8,19 \\
\hline Grzybowo & 4884 & 24497 & 5,02 \\
\hline Dźwirzyno & 27989 & 223003 & 7,97 \\
\hline Kołobrzeg & 384443 & 3008805 & 7,83 \\
\hline Sianożęty & 5221 & 47829 & 9,16 \\
\hline Ustronie Morskie & 44197 & 337783 & 7,64 \\
\hline Sarbinowo & 564 & 2036 & 3,61 \\
\hline Mielno & 9611 & 87790 & 9,13 \\
\hline Łazy & 3734 & 14700 & 3,94 \\
\hline
\end{tabular}




\begin{tabular}{|l|r|r|r|}
\hline \multicolumn{1}{|c|}{$[1]$} & {$[2]$} & {$[3]$} & {$[4]$} \\
\hline Dąbki & 22076 & 253292 & 11,47 \\
\hline Darłówko & 45638 & 293860 & 6,44 \\
\hline Jarosławiec & 12074 & 98082 & 8,12 \\
\hline Ustka & 75064 & 524602 & 6,99 \\
\hline Łeba & 81755 & 480256 & 5,87 \\
\hline Białogóra & 10541 & 65417 & 6,21 \\
\hline Władysławowo & 159489 & 692592 & 4,34 \\
\hline Jastarnia & 75308 & 350307 & 4,65 \\
\hline Hel & 6001 & 23328 & 3,89 \\
\hline Gdynia & 116810 & 269344 & 2,31 \\
\hline Sopot & 196363 & 605696 & 3,08 \\
\hline Gdańsk & 628428 & 1537077 & 2,45 \\
\hline Stegna & 42719 & 220770 & 5,17 \\
\hline Sztutowo & 116 & 1193 & 10,28 \\
\hline Krynica Morska & 43768 & 219814 & 5,02 \\
\hline
\end{tabular}

Źródło: opracowanie własne.

Według danych Banku Danych Lokalnych GUS, miastami o najwyższej liczbie osób korzystających z noclegów na polskim wybrzeżu są: Gdańsk (628 428), Kołobrzeg (384 443), Świnoujście (232 825), Sopot (196 363) i Międzyzdroje (135 499). Według tego samego źródła danych najmniej turystów korzystających z noclegów odnotowuje się w: Sztutowie, Sianożętach, Międzywodziu oraz Sarbinowie. Należy jednak pamiętać, że z uwagi na brak dotychczas wypracowanej przez GUS metodologii badawczej w zakresie pozyskiwania wyczerpujących danych dotyczących bazy noclegowej oraz wykorzystania jej w celach noclegowych oficjalne dane GUS, dotyczące zagospodarowania i ruchu turystycznego są w znacznej mierze niedoszacowane.

Najwięcej udzielono noclegów w Kołobrzegu (3 008 805), Gdańsku (1537 077), Świnoujściu (1 454 669), Niechorzu (760 358) i Międzyzdrojach (606 178). Najmniej w grupie badanych miejscowości wybrzeża udzielono noclegów w Międzywodziu (728 - według oficjalnych danych Banku Danych Lokalnych GUS), Sarbinowie (564) i Sztutowie (116 udzielonych noclegów).

Na podstawie liczby korzystających z noclegów oraz liczby udzielonych noclegów określono w przybliżeniu średni czas pobytu w miejscowościach nadmorskich. Najwyższe średnie długości pobytu odnotowano dla Dąbek $(11,47$ dni), Jarosławca $(8,12)$, Rewala $(9,61)$, Mielna $(9,13)$ oraz Sztutowa $(10,13)$. W celu oceny związku dostępności poszczególnych miejscowości 
z rejestrowanym ruchem turystycznym obliczono współczynniki korelacji rang Spearmana (tab. 6).

Tab. 6. Współczynniki korelacji rang Spearmana pomiędzy cechami opisującymi dostępność przestrzenną i ruch turystyczny w miejscowościach nadmorskich

\begin{tabular}{|c|c|c|c|c|c|c|}
\hline \multirow[b]{2}{*}{ Wyszczególnienie } & \multirow{2}{*}{$\begin{array}{c}\text { Liczba } \\
\text { turystów }\end{array}$} & \multirow{2}{*}{$\begin{array}{c}\text { Udzielone } \\
\text { noclegi }\end{array}$} & \multirow{2}{*}{$\begin{array}{l}\text { Długość } \\
\text { pobytu }\end{array}$} & \multicolumn{3}{|c|}{ Średnia odległość } \\
\hline & & & & $\begin{array}{c}\text { rzeczy- } \\
\text { wista }\end{array}$ & $\begin{array}{c}\text { naj- } \\
\text { krótsza }\end{array}$ & $\begin{array}{r}\text { czasowa } \\
\text { najkrótsza }\end{array}$ \\
\hline Liczba turystów & 1 & 0,33 & 0,27 & $-0,07$ & $-0,20$ & 0,20 \\
\hline Liczba udzielonych noclegów & 0,33 & 1 & 0,20 & 0,08 & $-0,11$ & $-0,04$ \\
\hline Długość pobytu & 0,27 & 0,20 & 1 & $-0,77$ & $-0,97$ & $-0,36$ \\
\hline Średnia odległość rzeczywista & $-0,07$ & 0,08 & $-0,77$ & 1 & 0,92 & 0,52 \\
\hline $\begin{array}{l}\text { Średnia najkrótsza odległość } \\
\text { drogowa }\end{array}$ & $-0,20$ & $-0,11$ & $-0,97$ & 0,92 & 1 & 0,44 \\
\hline $\begin{array}{l}\text { Średnia najkrótsza odległość } \\
\text { czasowa }\end{array}$ & 0,20 & $-0,04$ & $-0,36$ & 0,52 & 0,44 & 1 \\
\hline
\end{tabular}

Źródło: opracowanie własne.

Obliczone wartości współczynników korelacji rang są istotne statystycznie przy poziomie istotności 0,05 . Istotne statystycznie zależności wykazano pomiędzy średnią najkrótszą odległością drogową oraz średnią najkrótszą odległością czasową a długością pobytu i średnią odległością rzeczywistą. Uzyskane wartości współczynników korelacji rang Spearmana wskazują na ujemne korelacje pomiędzy tymi cechami. Szczególnie wysokie ujemne korelacje dotyczą zależności średniej odległości rzeczywistej oraz średniej najkrótszej odległości drogowej i średniej długości pobytu. Nie wykazano istotnych statystycznie zależności w zakresie średniej odległości rzeczywistej, średniej najkrótszej odległości drogowej oraz średniej czasowej z danymi o liczbie turystów i liczbie udzielonych noclegów.

Przeprowadzona metodą grupowania Warda analiza skupień również nie pozwoliła na wyodrębnienie $\mathrm{w}$ grupie badanych miejscowości klas cechujących się większymi poziomami korelacji cech opisujących dostępność przestrzenną obszaru oraz ruch turystyczny w poszczególnych miejscowościach (rys. 1). Wyróżniono dwa główne skupienia, A - które tworzy miejscowość Kołobrzeg charakteryzująca się znacznymi różnicami od pozostałych miejscowości, przede wszystkim $\mathrm{w}$ zakresie znacznie wyższych wartości opisujących ruch turystyczny (zdecydowanie najwyższa liczba korzystających z noclegów i liczba udzielonych noclegów oraz jedna z wyższych średnich długości pobytu). 


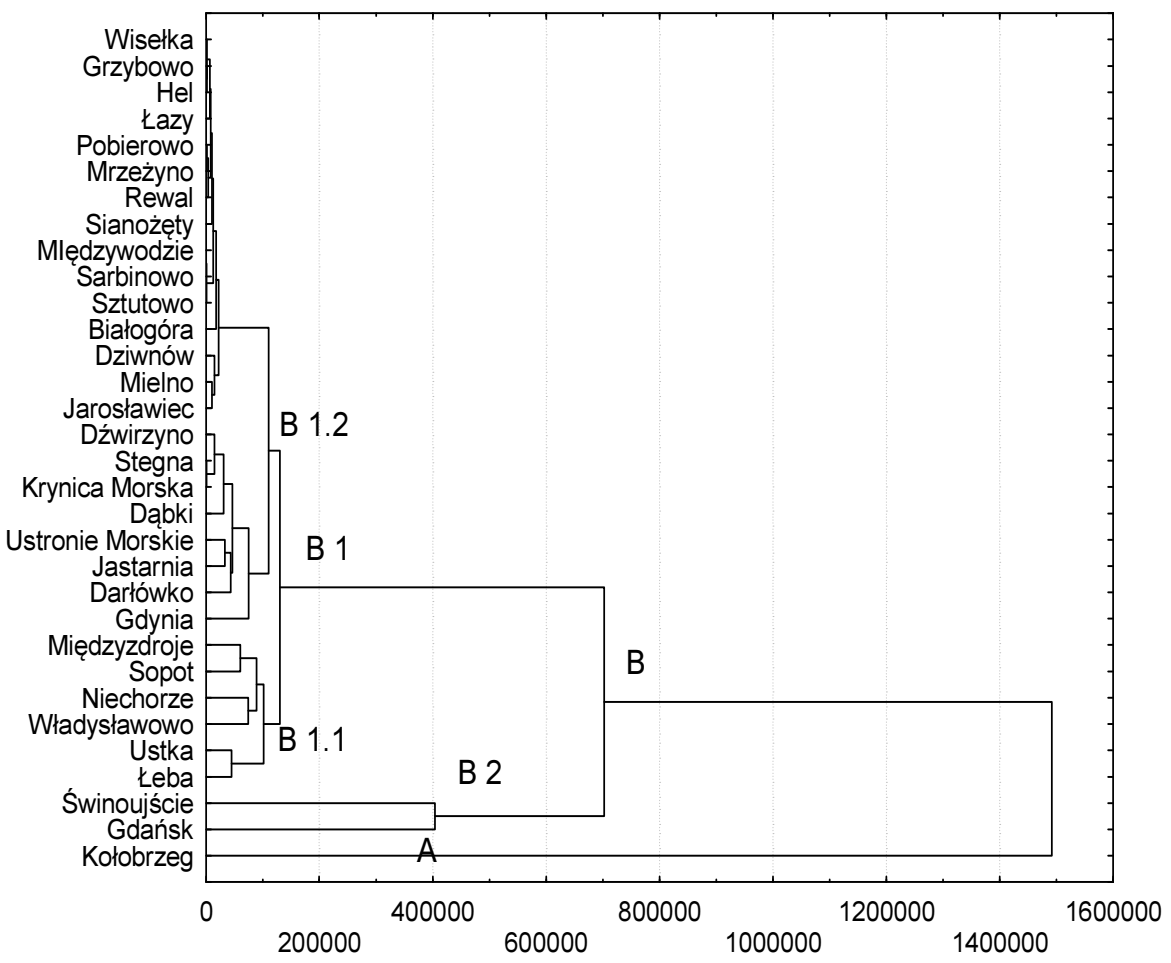

Rys. 1. Grupowanie metodą Warda cech opisujących dostępność przestrzenną miejscowości Źródło: opracowanie własne

Skupienie B składa się z dwóch mniejszych skupień B1 i B2. Na znacznie mniejsze skupienie B2 składają się Gdańsk oraz Świnoujście, miejscowości zbliżone do siebie ze względu na liczbę korzystających z noclegów oraz liczbę udzielonych noclegów, przy znacznie mniejszych podobieństwach w zakresie pozostałych cech. Skupienie B1 składa się z dwóch mniejszych skupień B.1.1 oraz B.1.2. Skupienie B.1.1 tworzą Międzyzdroje, Władysławowo, Sopot, Niechorze, Ustka i Łeba - miejscowości charakteryzujące się wysoką korelacją $\mathrm{w}$ zakresie średnich odległości rzeczywistych oraz liczby korzystających z noclegów. Skupienie B.1.2 jest znacznie bardziej rozproszone. Tworzą je pozostałe miejscowości, które charakteryzuje znacznie mniejszy stopień korelacji cech opisujących zarówno ich dostępność, jak i intensywność ruchu turystycznego. 


\section{Podsumowanie}

Przeprowadzona na potrzeby niniejszego opracowania analiza nie pozwala wykazać w sposób jednoznaczny korelacji pomiędzy dostępnością przestrzenną a danymi opisującymi ruch turystyczny. Brak wyraźnych związków pomiędzy dostępnością przestrzenną nadmorskich miejscowości turystycznych a miernikami opisującymi ruch turystyczny może pośrednio wskazywać, że intensywność ruchu turystycznego, opisywana liczbą odwiedzających, liczbą udzielonych noclegów oraz średnią długością pobytu turysty, jest skorelowana silniej z innymi czynnikami, np. skalą zagospodarowania turystycznego miejscowości lub cechami opisującymi warunki naturalne dla funkcjonowania turystyki wypoczynkowej (długość sezonu kąpielowego, średnie nasłonecznienie, średnie temperatury lata). $Z$ drugiej strony brak wyraźniejszej korelacji pomiędzy cechami opisującymi dostępność turystyczną miejscowości nadmorskich oraz cechami opisującymi ruch turystyczny może pośrednio wynikać z braku precyzyjnych danych dotyczących ruchu turystycznego, które odzwierciedlałyby w sposób wyczerpujący skalę ruchu turystycznego.

\section{Bibliografia}

KOMORNICKI T., ŚLESZYŃSKI P., ROSIK P., POMIANOWSKI W., 2010, Dostępność przestrzenna jako przestanka kształtowania polskiej polityki transportowej, „Biuletyn”, Komitet Przestrzennego Zagospodarowania Kraju PAN, 241, s. 16-34.

MIEDZIŃSKI M., 2011, Kołobrzeg jako centrum turystyki uzdrowiskowo-wypoczynkowej po 20 latach przemian ustrojowych (1989-2009), [w:] B. Krakowiak, J. Latosińska (red.), Turystyka polska w latach 1989-2009, ser. „Warsztaty z Geografii Turyzmu”, Wyd. Uniwersytetu Łódzkiego, Łódź, s. 115126.

MILEWSKI D., 2010, Dostępność transportowa jako element ksztattujący potencjat turystyczny województwa zachodniopomorskiego, Zeszyty Naukowe 590, „Ekonomiczne Problemy Usług”, 592, s. 509-519.

MILEWSKI D., 2011, Dostępność transportowa jako czynnik kształtujący atrakcyjność turystycznq województwa zachodniopomorskiego, Zeszyty Naukowe, 627, „Ekonomiczne Problemy Turystyki”, 16, s. 181-201.

MILEWSKI D., 2012, Dostępność transportowa województwa zachodniopomorskiego dla ruchu turystycznego. Popyt turystyczny - uwarunkowania, Zeszyty Naukowe, 698, "Ekonomiczne Problemy Usług", 83, s. 415-427.

PARZYCH K., 2010, Determinants of tourist activity and tourist destination perception on the example of selected coastal resorts. The comparison of Ustka and Łeba resorts, „Baltic Coastal Zone”, 14, Słupsk. 